Jurnal Agribis

Vol. 7, No.2, Oktober Tahun 2021

\title{
ANALISIS USAHA PEMBENIHAN IKAN GURAMI
}

\author{
Bambang Tri Kurnianto' \\ 1,Program Studi Agribisnis, Fakultas Pertanian, Universitas Tulungagung
}

\begin{abstract}
ABSTRAK
Usaha ikan gurami sangat profitabel karena dapat dibudidaya mulai dari telur di sarang, bibit yang memiliki ukuran kecil atau besar hingga menjadi induk, atau sebagai ikan konsumsi. Ikan gurami masih sangat diminati dengan berbagai ukuran sangat ramai dipasaran. Para konsumen berebut benih hingga keluar kota dengan ukuran yang diinginkan tidak mudah, yang dimana permintaan dari dalam kotapun belum bisa terpenuhi secara keseluruhan. Tujuan dari penelitian ini yaitu untuk mengidentifikasi biaya yang digunakan dalam berproduksi mengenai budidaya ikan gurami serta mengidentifikasi pendapatan dari hasil budidaya ikan gurami dengan menganalisis apakah usaha pembenihan ikan gurami tersebut laba/rugi. Lokasi penelitian dilakukan dengan cara sengaja (purpossive) di Desa Mirigambar Kecamatan Sumbergempol Kabupaten Tulungagung. Sampel penelitian adalah petani pembenihan ikan gurami dari Desa Mirigambar, Tulungagung. Peneliti dalam penelitian ini menggunakan metode deskriptif kuantitatif dan menggunakan teknik pengambilan data, yang mencakup data primer dan sekunder. Peneliti menggunakan analisis pengujian revenue cost $(R / C)$ ratio yang dimana digunakan untuk mengidentifikasi pendapatan dari budidaya ikan gurami. Adapun hasil pada penelitian ini adalah dimana tingkat pendapatan bersih yang diterima per paket benih ikan gurami yaitu sebesar $\mathrm{Rp} 2.292 .466,67$ dengan pengujian revenue cost $(\mathrm{R} / \mathrm{C})$ ratio sebesar 1,68 dimana usahatani pembenihan ikan gurami tergolong menguntungkan bagi masyarakat menengah dan layak untuk dikembangkan khususnya di daerah dilakukannya penelitian.
\end{abstract}

Kata Kunci : pembenihan, biaya produksi, pendapatan, ikan gurami

\section{ABSTRACK}

The gourami business is very profitable because it can be cultivated from eggs in nests, seeds that have small or large sizes to become broodstock, or as fish for consumption. Gouramy fish is still in great demand with various sizes very crowded in the market. Consumers fighting for seeds to get out of town with the desired size is not easy, which is where the demand from with in the city can't be fulfilled as a whole. The purpose of this study is to identify the costs used in the production of gouramy cultivation and to identify the income from gouramy cultivation by analyzing whether the gouramy hatchery business is profit/loss. The location of the research was carried out purposively in Miri Gambar Village, Sumbergempol District, Tulungagung Regency. The research sample was carp hatchery farmers from Miri Gambar Village, Tulungagung. Researchers in this study used quantitative descriptive methods and used data collection techniques, which included primary and secondary data. The researcher used an analysis of revenue cost $(R / C)$ ratio testing which was used to identify income from gouramy 
cultivation. The results in this study are where the level of net income received per package of gouramy seeds is $\mathrm{Rp} .2,292,466.67$ with a revenue cost $(\mathrm{R} / \mathrm{C})$ ratio of 1.68 where the gouramy hatchery farming is classified as profitable for middle and middle class people. feasible to be developed, especially in the area of research.

Keywords: hatchery, production costs, income, gouramy

\section{PENDAHULUAN}

Indonesia merupakan wilayah yang memiliki perairan sekitar 5,8 juta $\mathrm{km}^{2}$, dan tahun 1998 memiliki garis pantai sepanjang $91.181 \mathrm{~km}$ dan didalamnya terkandung sumberdaya perikanan serta kelautan dan memiliki potensi yang cukup besar untuk dijadikan sebagai tumpuan dalam pembangunan ekonomi berbasis sumber daya alam. Ikan gurami menjadi salah satu jenis ikan yang cukup potensial dibudidayakan di Indonesia. Banyak faktor yang menjadikan prospek budidaya ikan gurami menjadi sangat menjanjikan. Sedangkan faktor pendukung tersebut diantaranya adalah lahan untuk budidaya gurami masih sangat banyak tersedia, benih dan pakannya mudah didapat, serta data tentang cara budidayanya cukup memadai (Agromedia, 2007).

Gurami termasuk jenis ikan air tawar yang sudah lama dikenal orang dan telah banyak dibudidayakan. Gurami apabila dibandingkan ikan air tawar namun termasuk makhluk yang lamban dalam proses pertumbuhan. Pada ukuran tertentu gurami tumbuh dengan cepat apabila diberikan makanan yang jumlahnya cukup dan mutunya. Gurami biasanya juga dijual dan dipasarkan baik didalam negeri dan juga memiliki potensi dipasarkan keluar negeri.

Ikan gurami memiliki potensi yang cukup bagus karena bisa dibudidayakan dari telur yang berada disarang, bibit yang memiliki ukuran kecil atau besar hingga menjadi induk, atau sebagai ikan konsumsi. Ikan gurami masih sangat diminati dengan berbagai ukuran sangat ramai dipasaran. Para konsumen berebut benih hingga keluar kota dengan ukuran yang diinginkan tidak mudah, yang dimana permintaan dari dalam kotapun belum bisa terpenuhi secara keseluruhan. Meski cukup menjanjikan tak menyangka bahwa resiko kematian benih ikan gurami mencapai 20\%. Penyebab tingginya kematian dikarenakan kurang bagusnya air kolam dan predator seperti kodok, ular, belut, dan keong. Untuk mencegah serangan penyakit seharusnya memberikan antibiotik alami berupa dedaunan seperti sente, daun pisang batu, gedebog/batang pisang yang dicacah, jantung pisang (Riana 2015).

Dari berbagai keunggulan-keunggulan tersebut di atas, maka saya tertarik untuk menganalisa berbagai kegiatan Usaha Penetasan Telur Ikan Gurami dalam proses 
pemeliharaan dan perawatan ini menggunakan tenaga kerja manusia. Oleh sebab itu diperlukan ketelitian dalam memelihara telur ikan gurami tersebut hingga menetas sampai bisa dipasarkan kepada konsumen tergantung dari permintaan konsumen. Hampir semua ukuran benih ikan gurami mendapatkan permintaan yang sangat tinggi dari semua konsumen. Di dalam pemeliharaan telur ikan gurami yang cukup rumit dibutuhkan ketlatenan dan ketelitian, apalagi kalau sudah menjadi larva itu cukup sulit, fase inilah yang merupakan masa kritis yang bisa menyebabkan kematian dengan berbagai faktor.

\section{METODE PENELITIAN}

Pada penelitian ini penulis melakukan penelitian di Desa Mirigambar, Kecamatan Sumbergempol, Kabupaten Tulungagung dengan alasan bahwa di desa ini banyak petani ikan gurami dari mulai penetasan telur, pendederan, sampai konsumsi. Selain itu juga daerah penelitian relatif dekat dengan Populasi menurut Sugiyono (2003:117), adalah daerah generalisasi yang terdiri dari objek atau subjek yang memiliki kualitas.

Peneliti menggunakan teknik analisis untuk mengetahui pendapatan dari usaha pembenihan ikan gurami adalah dengan analisis pendapatan yang diterima. Sedangkan untuk mengetahui biaya yaitu dengan menggunakan analisis semua biaya yang telah dikeluarkan dalam usaha pembenihan ikan gurami, untuk menghitung keuntungan dengan menggunakan selisih dari pendapatan dan biaya usahatani.

\section{HASIL DAN PEMBAHASAN}

Melihat dari hasil studi lapang, peneliti dapat memberikan beberapa hasil perhitungan analisis usaha pembenihan gurami. Dari hasil perhitngan pembelian telur ikan gurami diperoleh dengan perhitungan sebagai berikut:

\section{Rata-rata biaya pembelian telur ikan gurami per paket =}

\section{$17.600 .000=\operatorname{Rp} 429.00,00$}

\section{1}

pembelian telur setiap petani ikan berbeda-beda karena disesuaikan berdasarkan banyak kolam yang dimilikinya. Kolam berukuran $5 \mathrm{~m} \times 7 \mathrm{~m}$ dengan kedalaman air $120 \mathrm{~cm}$ dapat diisi 1 paket ikan gurami yang baru menetas. Telur ikan gurami ditebar dalam bak fiber, kemudian 
setelah telur-telur tersebut menetas, semua ikan bisa dipindahkan ke kolam. Dalam pembelian telur ikan gurami 1 (satu) paket rata-rata berjumlah 10 ribu sampai dengan 11 ribu telur ikan gurami. Harga 1 (satu) paket telur ikan gurami tidak menentu tergantung cuacanya, pada saat melakukan penelitian ini harga telur ikan gurami per 1 (satu) paket adalah Rp. 400.000,- atau dengan rata-rata harga per butir sebesar Rp. 40,-. Harga tersebut sudah termasuk pengiriman sampai rumah.

Pada perhitungan pembelian pakan per paket dapat diketahui dalm berhitungan berikut ini:

\section{Rata-rata biaya pembelian pakan per paket $=$}

$$
\frac{\operatorname{Rp} 30.660 .000,00}{21}=\operatorname{Rp} 1.460 .000,00
$$

Biaya pembelian pakan masing-masing petani tidak sama karena banyaknya ikan yang dibudidayakan juga tidak sama. 1 (satu) paket ikan gurami dengan banyak 10 ribu sampai 11 ribu menghabiskan biaya pakan rata-rata sebesar Rp. 1.460.000,-- Biaya pakan tersebut meliputi cacing sutra, pelet udang FENG LI 1 sak, MS PRIMA FEED/PF 5001 sak, MS PRIMA FE Pendapatan yang dimaksud disini adalah pendapatan dari penjualan ikan gurami. Rata-rata dalam pemanenan per paket ikan gurami menghasilkan 7.000 sampai dengan 7.500 ikan gurami dengan 3 ukuran yang berbeda. Ukuran pertama yaitu seukuran silet atau kurang lebih $4 \mathrm{~cm}$ dengan harga jual sebesar Rp 1.000,00. Ukuran kedua yaitu dibawah ukuran silet atau kurang lebih $3 \mathrm{~cm}$ dengan harga jual sebesar Rp 700,00. Ukuran yang terakhir yaitu ukuran di bawahnya lagi atau kurang lebih $2 \mathrm{~cm}$ dengan harga jual sebesar Rp 500,00. Berikut ini merupakan tabel penjualan ikan gurami dari sampel yang diambil di Desa Mirigambar:

Perhitungan analisis keuntungan dari usaha ternak gurami ini adalah sebagai berikut:

Rata-rata tingkat pendapatan yang diterima per paket:

$$
\begin{aligned}
& S=T R-T C \\
& \mathrm{TR}=\operatorname{Rp} 5.652 .466,67 \\
& \mathrm{TC}=\mathrm{Rp} 400.000,00+R p 1.460 .000,00+R p 1.300 .000,00+R p \\
& 200.000,00 \\
& =\quad \operatorname{Rp} 3.360 .000,00 \\
& \mathrm{~S}=\operatorname{Rp} 5.652 .466,67-\operatorname{Rp} 3.360 .000,00 \\
& =\underline{R p 2.292 .466,67}
\end{aligned}
$$


1. Pengujian R/C Ratio

$R / C=$ pendapatan kotor $/$ biaya total

$>1$ menguntungkan

$=1 \mathrm{BEP}$ (Break Event Point)

$<1$ rugi

$>\quad$ Rata-rata total biaya per paket

$R p 400.000,00+R p 1.460 .000,00+R p 1.300 .000,00+R p 200.000,00$

$=\operatorname{Rp} 3.360 .000,00$

$>\quad$ Rata-rata total pendapatan per paket $=\mathbf{R p} 5.652 .466,67$

$>\quad$ Analisis usaha Pembenihanikan gurami $\mathrm{R} / \mathrm{C}$ ratio

$$
=\frac{R p 5.652 .466,67}{R p 3.360 .000,00}=1,68
$$

Dari data di atas dapat dilihat bahwa analisis metode budidaya ikan gurami dengan R/C ratio sebesar 1,68 yang artinya bahwa usaha tersebut tergolong menguntungkan karena nilai pendapatan/penjualan lebih besar daripada biaya yang telah dikeluarkan untuk melakukan proses usaha tersebut.

Jadi dapat disimpulkan bahwa budidaya ikan gurami tergolong menguntungkan bagi masyarakat menengah, dan layak untuk dikembangkan khususnya di Desa Mirigambar karena jika dilihat dari segi input usaha, sebagian besar penduduk Desa Mirigambar memiliki lahan kosong yang belum dimanfaatkan sehingga bisa dimanfaatkan untuk usaha Pembenihanikan gurami, juga sebagian besar dari penduduk Desa Mirigambar telah memiliki keahlian di bidang perikanan. Selain itu juga, ikan gurami saat ini sangat diminati oleh konsumen.

\section{KESIMPULAN DAN SARAN}

\section{KESIMPULAN}

Simpulan yang dapat diambil dari penelitian hasil dari pembahasan oleh peneliti adalah sebagai berikut:

1. Biaya produksi rata-rata petani pembudidaya ikan gurami sebesar $\mathrm{Rp} 3.360 .000,00$ per paket, 
2. Pendapatan rata-rata petani dalam budidaya ikan gurami per satu paket adalah $=\mathrm{Rp}$. 5.652.466,67. Dari pendapatan kotor ini menguntungkan bersih yang diterima petani ikan adalah = Rp. 2.292.466,67 per paket,

3. Dari hasil analisa didapat $\mathrm{R} / \mathrm{C}$ ratio sebesar 1,68 berarti $>1$ yang menyatakan bahwa budidaya ikan gurami menguntungkan.

\section{S A R A N:}

1. Dari data di atas saya sebagai penulis dan peneliti mengharapkan untuk segera disosialisasikan kepada masyarakat Desa Mirigambar bahwa dalam berusahatani ikan tergolong menguntungkan dan sangat cocok untuk dilakukan.

2. Dari data lapangan dan dari sumber petani yang saya teliti masalah utama dalam analisis metode budidaya ikan gurami adalah hama dan penyakit.

3. Petani harusnya sadar akan pentingnya pengetahuan penggunaan obat-obatan, sehingga dosis yang diberikan tidak sampai melebihi kuota, para petani juga harus selalu berkembang dengan teknologi perikanan yang ada, sehingga hasil produksi juga meningkat.

4. Pemerintah juga harus sadar dan berperan aktif dalam upaya meningkatkan produksi hasil budidaya perikanan. 